УДК 008(477)"14/16":930.2

DOI 10.31.65/2520-6966-2020-13i-99-238-246

\title{
В. А. Дмитренко
}

кандидат історичних наук, доцент кафедри культурології та методики викладання культурологічних дисциплін Полтавського національного педагогічного університету ім. В. Г. Короленка

\section{Культура ранньомодерної України в сучасних історичних студіях}

У статті розглянуто головні напрями вивчення ранньомодерної української культури в сучасних історичних студіях. Предметом уваги стали монографрічні дослідження, котрі побачили світ після 2000-го року. Вважаємо, що саме вони є квінтесенцією наукового доробку й якнайкраще представляють напрацювання в досліджуваній сфрері. З'ясовано, що спещіалізованих історіографрічних праць, у яких би аналізувався стан дослідження української культури ранньомодерного часу, на сьогодні немає. Вирізнено два імовірні шляхи кризи "ідентичності історика", їх відмінності між собою не так предметом дослідження, як методологією його виконання та понятійним апаратом, який використовують науковці. Охарактеризовано позицію прихильників, які вважають, що головне завдання дослідника - розвіювання фральсифрікацій, відкриття замовчуваних сторінок і конструювання нового історичного канону та позиції адептів, згодних з необхідністю позбутися догматичних нашарувань, заідеологізованості та фальші в контексті нового погляду на вітчизняну історію через опанування методик, випрацюваних за межами пострадянського інтелектуального простору, акцентуючи увагу на необхідності ведення діалогу зі своїми "західними" колегами однією мовою, що сприятиме включенню українського історичного наративу до світового історико-інфрормаційного простору. Фундаментальним виданням періоду 2001-2013 рр. є "Історія української культури" " п'яти томах, другий та третій томи якого містять багатий фактографрічний матеріал із української культури ранньомодерного часу. Водночас, відзначаємо появу праць, які попри те, що жоден із авторів не позиціонує себе як історика культури, мають виразне культурно-антропологічне спрямування. Саме вони презентують нові напрями вивчення ранньомодерної української історії, засновані на методолодії "нової культурної історії". На нашу думку, саме такі дослідження сприяють поглибленому розумінню культури ранньомодерного часу.

Ключові слова: гранд-наратив, історіографрія, "нова культурна історія", ранньомодерний час, українська культура.

Ситуація постмодерну, що нею окреслюють стан, у якому перебуває сучасна інтелектуальна спільнота, привнесла виразний культурний чинник у гуманітарні студії в цілому та в ремесло історіописання зокрема. Стає хрестоматійною теза про релевантність понять "суспільство" 
та "культура" та про неможливість збагнути одне з них у відриві від іншого. Це вкотре піднімає на поверхню питання про поєднання в історичній науці традиції та новації й актуалізує дискурс про напрями розвитку історичних досліджень. Тож зрозуміла потреба в появі узагальнюючих історіографічних робіт, котрі б відповідали на питання: що ми зробили та куди маємо рухатися далі? Особливої ваги такі студії набувають в постколоніальних країнах, що, відмовляючись від імперської (радянської) спадщини, шукають нові орієнтири.

За останні роки таких праць з'явилося чимало. Пригадаємо дискурсивні публікації на сторінках "Українського історичного журналу". Концептуальні твори Зенона Когута [1], Ярослава Дашкевича [2], Ярослава Грицака [3], Наталі Яковенко [4], Григорія Касьянова й Олексія Толочка [5] та інших. Узагальнюючі монографії Леоніда Зашкільняка [6] та Ірини Колесник [7].

Наслідком обговорення стало прокладення двох імовірних шляхів подолання того, що Наталя Яковенко охрестила кризою "ідентичності історика" [4, с. 23]. Ці дороги, на нашу думку, різняться між собою не так предметом дослідження, як методологією його виконання та понятійним апаратом, який використовують науковці.

Прихильники першого головне завдання дослідника вбачають в розвіюванні фальсифікацій, відкритті замовчуваних сторінок і конструюванні нового історичного канону, котрий служитиме формуванню державницької свідомості та колективної національної пам'яті. При цьому використовується термінологічна база та методологія, випрацювана українською історіографрією впродовж XIX-XX століть.

Адепти іншого шляху теж вважають, що необхідно позбутися догматичних нашарувань, заідеологізованості та фральші й підкреслюють необхідність нового погляду на вітчизняну історію. Проте зробити це пропонують через опанування методик, випрацюваних за межами пострадянського інтелектуального простору. Вони наголошують на необхідності ведення діалогу зі своїми "західними" колегами однією мовою, що сприятиме включенню українського історичного наративу до світового історико-інформаційного простору.

Зрозуміло, що виділені нами шляхи є своєрідними ідеальними моделями й на практиці в чистому вигляді зустрічаються рідко. Втім, вони задають координати для дослідників, які спеціалізуються на різних періодах і напрямах української історії. Зокрема, й тих істориків, які вивчають ранньомодерну українську культуру.

Термін "ранньомодерний час", чи "ранньомодерна доба", запроваджений Іваном Лисяком-Рудницьким на позначення періоду в українській історії від Люблінської унії до кінця XVIII століття, міцно 
вкоренився у вітчизняній історичній науці. Значна кількість дослідників саме з цим часом пов'язує становлення модерної української нації. Коли ж взяти до уваги, що на цю епоху припадає розквіт козаччини, із якою традиційно більшість сучасних українців асоціюють свою минувшину, то стає зрозумілим величезний інтерес учених до цього періоду нашої історії.

Популяризуючи свого часу власний варіант періодизації української історії, взорований на європейський досвід, Іван Лисяк-Рудницький особливу увагу звернув на аналіз культурних явищ, які визначають обличчя історичних епох. Зокрема, ренесанс, реформація та бароко проголошується ним основною темою культурного та інтелектуального життя у пізньосередньовічний та ранньомодерний період, а просвітництво й романтизм стають визначальними для "довгого" XIX століття [8, с. 42-43].

Такий підхід був сприйнятий окремими вітчизняними істориками. До того ж, він був суголосний культурно-антропологічному спрямуванні, що його набуло світове історіописання в останній третині XX століття й яке поступово проникало в інтелектуальні кола пострадянських країн. Усе це зумовило появу низки досліджень культури ранньомодерної України, виконаних із застосуванням методик "нової культурної історії". Втім, якщо говорити про загальний стан речей, пов'язаних із дослідженнями історії української культури, то зауважимо, що в вітчизняній науці вкрай мало узагальнюючих історіографрічних студій, в яких би розглядалася проблематика, пов'язана з її вивченням. А спеціалізованих історіографічних праць, у яких би аналізувався стан дослідженнями української культури ранньомодерного часу, фрактично немає. Тож маємо парадоксальну ситуацію, за якої при значній кількості історичних досліджень цього періоду практично відсутні історіографрічні узагальнення.

Наголосимо, що в своїй розвідці ми зупинилися лише на дослідженнях істориків, оминувши напрацювання фрілософрів, мистецтвознавців, культурологів, літературознавців у цій царині. Переважно предметом нашої уваги стали монографрічні дослідження, котрі побачили світ після 2000 р. Ми виходили з того, що саме монографії, байдуже, колективні чи одноосібні, є квінтесенцією наукового доробку й якнайкраще представляють напрацювання в досліджуваній сфері.

Наш аналіз розпочнемо з фундаментального видання "Історія української культури" у п'яти томах, яке було оприлюднене впродовж 2001-2013 рр. під егідою Національної академії наук України. У контексті нашого дослідження звернемо увагу на другий і третій томи "Історії української культури", котрі побачили світ у 2001 та 2003 рр. 
Зокрема, у четвертому розділі другого тому представлена історія культури другої половини XVI - першої половини XVII століть. Третій же том охоплює часовий відрізок другої половини XVII та XVIII століття. Це хронологічно збігається з рамками ранньомодерної доби, запропонованої Іваном Лисяком-Рудницьким.

Оскільки авторами текстів до видання $є$ різні науковці, то ще у вступі до першого тому редактори задекларували свідомий відхід від спільних концепцій і методологій та проголосили, що кожен автор керується власними, прийнятними для нього фрілософсьькими принципами і методологічними засадами. У цьому ми вбачаємо як переваги, так і вади видання. Беззаперечним його здобутком є багатющий фактологічний матеріал, викладений у трактуванні непересічних учених. Поряд із традиційними для історії культури оглядами стану літератури, освіти, науки, архітектури, образотворчого мистецтва, театру та музики привертають увагу новаторські розвідки з політичної культури, релігійного життя, інтелектуальної думки, включені до багатотомника. Велика увага приділена аналізові культури міської та сільської спільнот із акцентуванням їхньої схожості й відмінності, досліджена виробнича культура та побут, культура родинних і гендерних взаємин. Усе це свідчить про розширене трактування поняття "культура" і "культурне життя", що його сповідують редактори видання, вочевидь, не без впливу праць представників "нової культурної історії".

Проте розподіл фактографічного матеріалу за томами і розділами потребує спільного бачення наповнення головних періодів української культури і виокремлення часових меж їхнього буття. Навіть за умови декларування безперервної тяглості української культури. В іншому випадку, складно збагнути, чому в передмові до другого тому період з XIII до першої половини XVII століття характеризується як "важлива доба в історії українського народу і його культури" [9]. Виникає питання: як ця доба має бути окреслена - пізнє середньовіччя, ранньомодерний час, період перебування українських земель у складі Литви та Польщі чи якось інакше? Та, що є визначальною культурною особливістю, котра уможливила об'єднати матеріал у одному томі, - Ренесанс, Реформація, Бароко?

Видається, що базою для такої періодизації залишається схема української історії, випрацювана представниками державницької школи української історіографії. Зокрема, хронологічні рамки другого тому перегукуються з етапом української історії від 1340 до 1648 рр., що його виділив Іван Крип'якевич як період перебування українських земель у складі Литви і Польщі. За такої логіки, правомірно виглядає й виокремлення окремим томом культури другої половини XVII i 
XVIII століть, адже вона вповні відповідає часу існування козацької держави [10]. Не заперечуючи вплив політичних процесів на культуру, все ж наголосимо, що, на нашу думку, некоректно вписувати культурні процеси в періодизацію, засновану на розвиткові державних і політичних інституцій. Усе це засвідчує, що питання періодизації розвитку української культури потребує подальшого обговорення. Зокрема, важливим $є$ питання про співвідносність хронологічних меж для політичних і культурних процесів в українській історії.

На нашу думку, матеріал четвертого розділу другого тому доречніше було б поєднати з матеріалом, уміщеним у третьому томі видання. Ми розуміємо логіку редакторів, які справедливо зауважили, що "є ряд процесів, перебіг яких був дуже повільним, і ті зміни, які вдається встановити, важко віднести до якогось конкретного часу" [9]. Такі процеси, насамперед, притаманні традиційно-побутовій культурі, котра виражається у виробничих традиціях, обрядах, щоденній побожності, сімейному побуті, гендерних взаєминах тощо. Разом із тим уважаємо, що конфесіоналізація, котру переживала Церква і суспільство в цей час, справила суттєвий вплив на населення й міцніше зв'язала традиційно-побутову культуру кінця XVI століття з двома наступними епохами, аніж із попередніми часами.

Якщо ж говорити про процеси в "елітарній культурі", започатковані в 70-90-х рp. XVI століття, то вони ще виразніше знайшли своє продовження в подальші двісті років. Діяльність Острозького вченого гуртка, Львівської братської школи, Києво-Могилянського колегіуму, протестантських та римо-католицьких освітніх закладів заклали підвалини до інтелектуальної експансії випускників "київських Атен" у другій половині XVII і XVIII століттях. Та й початки барокової літератури, визначальної для "високої культури" XVII-XVIII століть, зазвичай пов'язують із полемічними трактатами авторства Івана Вишенського. В цьому контексті слушними є зауваження Наталі Яковенко про те, що Річ Посполита "пішла, аби залишитися", бо, доклавши зусиль до руйнації ії як держави, еліта Гетьманщини успадкувала її культурно-політичні традиції.

Наступною групою праць, на які звернемо увагу, стануть дослідження науковців, які, попри різноманіття тем, джерел і методик їхньої інтерпретації, мають виразне культурно-антропологічне спрямування. Попри те, що жоден із авторів не позиціонує себе як історика культури, вважаємо, що їхні праці важливі для розкриття нових граней ранньомодерної української культури. Звісно, перелік праць, оглянутих нами, не вичерпує всіх напрацювань, здійснених у рамках 
"нової культурної історії". Втім саме вони найповніше презентують нові напрями вивчення ранньомодерної української історії.

Передовсім, звернемо увагу на дві праці Наталі Яковенко - "Паралельний світ. Дослідження з історії уявлень та ідей в Україні XVIXVII ст." [11] та "У пошуках Нового неба: Життя і тексти Йоаникія Ґалятовського" [12]. У першій авторка досліджує ранньомодерного українського шляхтича / козака, через реконструкцію його уявлень про нормативну / девіантну поведінку, поглядів на релігію, війну, суспільні цінності та ідеї. Показує трансформацію цих уявлень упродовж XVI-XVII століть. Тож перед нами спроба побачити людину минулого через узагальнення всіх аспектів їі діяльності в тогочасних культурних координатах.

Друга книга, на прикладі біографії знаного київського богослова, показує транслювання християнського досвіду "могилянської доби" у діяльності другого покоління вихованців Києво-Могилянської колегії, що дозволило витворити нове обличчя української культури. Праця підіймає широкий спектр питань, пов'язаних із освітою, культурними рецепціями, уявленнями та ідеями, колом читання київських книжників ранньомодерного часу.

Важливою для осмислення ранньомодерної культури є книга Сергія Плохія "Наливайкова віра: козаки та релігія в ранньомодерній Україні" [13]. Автор по-новому інтерпретує, здавалося б, освячену та непорушну тезу про споконвічну православність козаків, доводячи, що ставлення козацтва до православ'я пережило складну й часом суперечливу еволюцію. Використовуючи концепт "конфесіоналізація", науковець прослідковує співвідношення конфесійної, станової та етнічної ідентичностей як серед козацтва, так і в українському ранньомодерному суспільстві.

Загалом тема Церкви, міжконфесійних взаємин, повсякденних релігійних практик у ранньомодерний час $є$ надзвичайно популярною серед істориків. Основним лейтмотивом таких досліджень є подолання спрощених підходів до розуміння релігійного життя, а отже, збагачення культурної палітри тогочасного соціуму. Гарним прикладом цього $є$ запровадження історіографрічних концептів "київська традиція" та "київське християнство", здійснена Ігорем Скочилясом і Максимом Яременком [14]. Ними окреслено спільність соціорелігійних та культурних практик, які побутували в межах Київської митрополії після релігійного розколу 1596 р. Така єдність, на думку авторів, уможливлювалася спільною слов'яно-візантійською обрядовістю, "спільною пам'яттю", заснованою на уявленні про єдине коріння обох церков, церковнослов'янською мовою, богословською літературою. 
Разом із тим розробляються й нові сюжети з релігійної культури. Зокрема, Катерина Диса вперше здійснила ґрунтовне дослідження уявлень ранньомодерного українського населення про відьомство і чари [15]. Авторка зіставляє нормативні приписи із судовою практикою, розглядає вироки і з'ясовує, що найчастіше викликало підозри й слугувало підставою для звинувачення у відьомстві. Вона підкреслює, що ці справи є продуктом людських страхів, переживань і підозр, які $є$ невід'ємною складовою культури.

Останні дві монографрії підіймають маловивчені питання ставлення до смерті та дитинства в українській ранньомодерній культурі. Автор першої з них, Олена Замура, спираючись на матеріали історико-демографрічних досліджень, богословські трактати і фольклор, стверджує, що масові зустрічі з "великим шаленцем", особливо дітей, були звичним явищем у Гетьманщині та визначали світогляд та життєвий уклад її мешканців. На думку дослідниці, саме колосальна смертність здатна пояснити багато явищ повсякденної культури, як то правила й мотиви поведінки людей того часу [16].

У фокусі уваги Ігоря Сердюка - образ дитинства й уявлення про нього в культурі Гетьманщини. Основні герої твору: немовлята, наймити, школярі, сироти, учні ремісників, малолітні волоцюги, байстрюки, нащадки старшини, які складають під пером історика збірний образ дитини того часу. Дослідник, на основі численних прикладів, критикує концепцію "щасливого дитинства в козацькій Україні", популярну серед низки учених, стверджує, що "дитячого світу" тоді практично не існувало. Водночас наголошує, що дитяча праця в тогочасній культурі сприймалася не як фрорма визискування, а як необхідна складова соціалізації дитини. Автор досліджує низку важливих для розуміння тогочасної культури проблем. Наприклад, як ставилися до народження і смерті дитини, як уявляли посмертну долю дитячої душі, що розуміли під поняттям "багатодітність", як розв'язували проблеми 3 безпліддям, як відбувалося дорослішання дитини [17].

Таким чином, історики, які працюють в культурно-антропологічній парадигмі, зосереджують свою увагу на вивченні ментальності, релігійної культури, освіти, інтелектуального життя, ставлення до смерті та дитинства в українській ранньомодерній культурі. Такі студії суголосні світовим історіографічним тенденціям і виходять із широкого розуміння поняття "культура" як явища, що охоплює всі сфрери життя людини. На нашу думку, саме такі дослідження сприяють поглибленому розумінню культури ранньомодерного часу.

\section{Література}

1. Когут 3. Коріння ідентичности. Студії з ранньомодерної та модерної історії України. Київ: Критика, 2004. 352 с. 
2. Дашкевич Я. "... Учи неложними устами сказати правду": Історична есеїстка (1989-2008). Київ: Темпора, 2011. С. 329-330.

3. Грицак Я. Нарис історії України: Формування модерної української нації XIX-XX ст. Київ: Генеза, 1996. 360 с.

4. Яковенко Н. Нариси кризової історіографії. Критика. 2006. Число 1-2.

5. Касьянов Г., Толочко О. Національні історії та сучасна історіографрія: виклики і небезпеки при написанні нової історії України. Український історичний журнал. 2012. № 6. С. 4-24.

6. Українська історіографія на зламі XX і XXI століть: здобутки і проблеми / за ред. Леоніда Зашкільняка. Львів, 2004. 405 с.

7. Колесник І. Українська історіографія: концептуальна історія. Київ: Фенікс, 2013. 566 с.

8. Лисяк-Рудницький І. Історичні есе. Київ: Основи, 1994. Т. І. 554 с.

9. Історія української культури. Київ: Наукова думка, 2001. Т. 2. (Українська культура XIII - першої половини XVII століть). URL: http://litopys. org. ua/istkult2/ikult2. htm

10. Крип'якевич І. П. Історія України. Львів: Світ, 1990. 519 с.

11. Яковенко Н. Паралельний світ. Дослідження з історії уявлень та ідей в Україні XVI-XVII ст. Київ: Критика, 2002. 416 с.

12. Яковенко Н. У пошуках Нового неба: життя і тексти Йоаникія Ґалятовського. Київ: Критика, Laurus, 2017. 689 с.

13. Плохій С. Наливайкова віра: козаки та релігія в ранньомодерній Україні. Київ: Критика, 2005. 496 с.

14. Яременко М.В.Перед викликами уніфікації та дисциплінування: Київська православна митрополія у XVIII столітті. Львів: Вид-во УКУ, 2017. 272 с.

15. Диса К. Історія з відьмами. Суди про чари в українських воєводствах Речі Посполитої XVII-XVIII ст. Київ: Критика, 2008.

16. Замура О. "Великий шаленець": смерть і смертність в Гетьманщині XVIII ст. Київ: К. І. С., 2014. 240 с.

17. Сердюк І. Маленький дорослий: дитина й дитинство в Гетьманщині XVIII ст. Київ: К. І. С., 2018. 456 с.

\section{References}

1. Kohut, Z. (2004). Korinnya identychnosty. Studiyi z rann'omodernoyi ta modernoyi istoriyi Ukrayiny. Kyyiv: Krytyka. [in Ukraine].

2. Dashkevych, Ya. (2011). "...Uchy nelozhnymy ustamy skazaty pravdu": Istorychna eseyistka (1989-2008). Kyyiv: Tempora [in Russian].

3. Hrytsak, Ya. (1996). Narys istoriyi Ukrayiny: Formuvannya modernoyi ukrayins'koyi natsiyi XI-XX st. Kyyiv: Heneza [in Ukraine]. .

4. Yakovenko, N. (2006). Narysy kryzovoyi istoriohrafiyi. Krytyka, Chyslo 1-2. [in Ukraine].

5. Kas'yanov, H., Tolochko, O. (2012). Natsional'ni istoriyi ta suchasna istoriohrafiya: vyklyky i nebezpeky pry napysanni novoyi istoriyi Ukrayiny. Ukrayins'kyy istorychnyy zhurnal. № 6. S. 4-24 [in Ukraine].

6. Zashkil'nyak L., (eds.) (2004). Ukrayins'ka istoriohrafiya na zlami XX i XXI stolit': zdobutky i problemy. L'viv. 405 s. [in Ukraine]. 
7. Kolesnyk, I. (2013). Ukrayins'ka istoriohrafiya: kontseptual'na istoriya. Kyyiv: "Feniks", 566 s. [in Ukraine].

8. Lysyak-Rudnyts'kyy, I. (1994). Istorychni ese. Kyyiv: Osnovy, Vol. I. [in Ukraine].

9. Istoriya ukrayins'koyi kul'tury. Kyyiv: Naukova dumka, 2001. Vol. 2. (Ukrayins'ka kul'tura XIII - pershoyi polovyny XVII stolit'). URL: http://litopys. org. ua/istkult2/ikult2. htm

10. Kryp'yakevych, I. P. (1991). Istoriya Ukrayiny. L'viv: Svit. [in Ukraine].

11. Yakovenko, N. (2002). Paralel'nyy svit. Doslidzhennya z istoriyi uyavlen' ta idey v Ukrayini XVI-XVII st. Kyyiv: Krytyka [in Ukraine].

12. Yakovenko, N. U (2017). poshukakh Novoho neba: Zhyttya i teksty Yoanykiya Galyatovs'koho. Kyyiv: Krytyka, Laurus. [in Ukraine].

13. Plokhiy, S. (2005). Nalyvaykova vira: Kozaky ta relihiya $v$ rann'omoderniy Ukrayini. Kyyiv: Krytyka, $496 \mathrm{~s}$. [in Ukraine].

14. Yaremenko, M. V. (2017). Pered vyklykamy unifikatsiyi ta dystsyplinuvannya: Kyyivs'ka pravoslavna mytropoliya u XVIII stolitti. L'viv: Vydavnytstvo UKU [in Ukraine].

15. Dysa, K. Istoriya $z$ vid'mamy. Sudy pro chary $v$ ukrayins'kykh voyevodstvakh Rechi Pospolytoyi XVII-XVIII st. Kyyiv: Krytyka, 2008. [in Ukraine].

16. Zamura, O. "Velykyy shalenets"': smert' i smertnist' v Het'manshchyni XVIII st. Kyyiv: K. I. S., 2014. 240 s. [in Ukraine].

17. Serdyuk, I. Malen'kyy doroslyy: Dytyna y dytynstvo v Het'manshchyni XVIII st. Kyiv: K. I. S., 2018. 456 s. [in Ukraine].

\section{A. Dmytrenko}

candidate of Historical Sciences, Associate Professor of the Department of Cultural Studies and Methods of Teaching Cultural Studies at the Poltava V. G. Korolenko National Pedagogical University

\section{Culture of early modern Ukraine in nowadays historical studios}

The main directions of the study of early modern Ukrainian culture in modern historical studios are considered in the article. The subject of attention is the monographic studies that came to life after 2000. We believe that they are the quintessence of scientific work and represent the best in the field of research. It is found that there are no specialized historiographical works in which the state of the Ukrainian culture studies of early modern times is analyzed. We believe that researchers of cultural history characterized them by the same epistemological searches as the rest of historians. The main essence of which comes down to the question of the use of methodological developments of the Western historiography on domestic material. The five-volume "History of Ukrainian Culture" is a fundamental edition of 20012013. The second and third volumes contain rich factual material on Ukrainian culture of early modern times. At the same time, we note the emergence of works that, despite the fact that none of the authors position themselves as a historian of culture, have a distinct cultural and anthropological orientation. It is they who present new trends in the study of early modern Ukrainian history based on the methodology of "new cultural history". Among them are the study of mentality, religious culture, education, intellectual life, attitudes towards death and childhood and more. Such studies are in line with the world historiographical trends and come from a broad understanding of the concept of "culture" as a phenomenon that covers all spheres of human life. In our opinion, such research contributes to an in-depth understanding of the culture of early modern times.

Key words: grand-narrative, historiography, "new cultural history", early modern times, Ukrainian culture. 